\title{
STUDI EKSPERIMEN PERILAKU DINAMIK JEMBATAN PRESTRESSED CONCRETE-I GIRDER DENGAN MENGGUNAKAN AKSELEROMETER
}

\author{
Said Jalalul Akbar'), Maizuar ${ }^{2)}$, M. Fauzan ${ }^{3)}$, Burhanuddin ${ }^{4)}$ \\ ${ }^{1,2,3,4)}$ Jurusan Teknik Sipil, Fakultas Teknik, Universitas Malikussaleh, Aceh \\ email: saidjalalul.akbar@unimal.ac.id ${ }^{1)}$,maizuar@unimal.ac.id ${ }^{2)}$, \\ fauzanunimal@gmail.com ${ }^{3)}$,burhanuddin@unimal.ac.id ${ }^{4)}$ \\ DOI: http://dx.doi.org/10.29103/tj.v10i2.353
}

(Received: August 2020 / Revised: August 2020 / Accepted: September 2020)

\begin{abstract}
Abstrak
Jembatan merupakan salah satu sarana infrastruktur transportasi penghubung yang penting. Dalam masa layan kerusakan struktur sebuah jembatan dipengaruhi oleh bermacam faktor beban dan kondisi lingkungan. Struktur jembatan yang sudah menua (ageing bridge) dan kenaikan beban lalu lintas adalah subjek yang harus dimonitor pada pemeliharaan jembatan. Dalam rangka pengukuran kapasitas struktur perlu dilakukan pengawasan rutin dan evaluasi integritas konstruksi sipil dengan menggunakan metode tanpa merusak benda uji (Non Destructive Testing Techniques). Metode ini dapat memberikan informasi tentang respon struktur jembatan. Penelitian ini dilakukan untuk memperoleh data percepatan dengan menggunakan akselerometer yang akan diolah untuk mendapatkan respon struktur berupa frekuensi alami dan lendutan yang terjadi pada tengah bentang jembatan. Selanjutnya dengan menggunakan software Geopsy diperoleh frekuensi alami sebesar 4,3256 Hz. Sedangkan lendutan diperoleh dengan menggunakan software DADiSP sebesar $0,43 \mathrm{~cm}$ pada pembebanan truk 28 ton dan lendutan sebesar $0,5 \mathrm{~cm}$ pada beban lalu lintas normal.
\end{abstract}

Kata kunci: Akselerometer, frekuensi alami, jembatan, lendutan, perilaku dinamik

\begin{abstract}
Bridges are crucial transport infrastructure. In practice, structural damage of a bridge accumulates over its life-span caused mainly by loadings and environmental condition. Ageing bridge structures subject to increasing demand from heavy traffic loading is subject in monitoring and maintenance of bridges. Structural capacity and integrity of bridges need to be routinely monitored and evaluated using non dectructive testing (NDT) techniques. The NDT method could provide information on structural respond of bridges. This study investigates structural respond of a bridge (e.g., natural frequency and displacement) using accelerometer sensor. The results of study show that the natural frequency obtained using Geopsy software is $4,3256 \mathrm{~Hz}$. Using DADiSP software, the displacement of the bridge is obtained $0,43 \mathrm{~cm}$ under design truck load of 28 ton and displacement of $0,5 \mathrm{~cm}$ under normal traffic condition.
\end{abstract}

Keywords: Accelerometer, natural frequency, bridge, displacement, dynamic behaviour

\section{Latar Belakang}

Jembatan merupakan sarana infrastruktur transportasi yang menghubungkan dua buah tempat yang terpisah oleh adanya danau, sungai, laut dan sebagainya (Maizuar et al., 2019). Pembangunan sebuah jembatan akan berdampak terhadap 
peningkatan ekonomi, aspek sosial dan lingkuangan bagi masyarakat suatu daerah, akan tetapi dalam masa layan, kapasitas struktur sebuah jembatan akan dipengaruhi oleh berbagai macam faktor beban dan kondisi lingkungan seperti, beban gempa, korosi, faktor usia, dan beban lalu lintas. Perubahan faktor-faktor tersebut dapat menyebabkan kerusakan jembatan lebih cepat dan mengurangi sisa umur layannya. Kerusakan struktur jembatan akan membutuhkan biaya perbaikan yang sangat besar. Untuk menghindari kerugian tersebut, diperlukan penilaian terhadap kondisi kesehatan jembatan melalui informasi respon perilaku dinamiknya (Zhang et al., 2016, Maizuar et al., 2020b).

Structural Health Monitoring System (SHMS) adalah sebuah sistem monitoring kesehatan struktur bangunan berbasis teknologi yang terdiri dari berbagai jenis sensor yang dapat memberikan data-data nyata dari elemen-elemen bangunan (Kolakowski, 2007). SHMS merupakan implementasi dari strategi pengidentifikasian kerusakan infrastruktur di bidang teknik sipil. Kerusakan tersebut didefiniskan sebagai bentuk perubahan dari sifat material dan/atau kerusakan umumnya terdiri dari empat tingkatan yaitu deteksi kerusakan, lokasi kerusakan, tipe kerusakan dan taraf kerusakan. SHMS ini bertujuan untuk memberikan informasi yang berkaitan dengan operasional dan pemantauan kondisi kesehatan dari sebuah struktur terutama jembatan yang memiliki beban hidup yang efektif tinggi, mewujudkan perencanaan pemeliharaan yang rasional dan ekonomis, serta mengidentifikasi penyebab terjadinya kondisi struktur yang tidak layak. Pemantauan terhadap kesehatan struktur jembatan dilakukan karena adanya beban-beban bekerja seperti beban mati, beban mati tambahan, dan beban hidup yang mempengaruhi terhadap umur pelayanan dari suatu jembatan. Selain adanya beban yang bekerja pada struktur jembatan, kesehatan jembatan juga dipengaruhi oleh faktor usia (ageing bridge). Dengan semakin menuanya struktur jembatan memungkinkan terjadinya penurunan pelayanan dari jembatan tersebut. Pemantauan terhadap kesehatan suatu struktur dapat dilakukan oleh manusia secara langsung di lapangan, tetapi hal ini kurang praktis karena penilaian manusia terhadap kondisi selalu berbeda-beda. Selain itu, di waktu tertentu kerusakan struktur dapat terjadi dalam struktur yang sulit teramati oleh mata manusia. SHMS dapat dikategorikan dalam beberapa tingkat identifikasi yaitu menentukan apakah adanya kerusakan pada struktur, menentukan adanya kerusakan serta lokasi kerusakan, menentukan adanya kerusakan, lokasinya serta menilai tingkat kerusakan dan menentukan adanya kerusakan, lokasinya, tingkat kerusakan serta memperkirakan usia pakai struktur (Comisu et al., 2017, Chen, 2018).

Non destructive test (NDT) adalah suatu cara yang dilakukan tanpa merusak struktur yang diuji. Pengujian ini sangat banyak dilakukan saat ini yaitu dengan menggunakan teknologi sensor yang bekerja sesuai dengan fungsinya masingmasing. Metode NDT bertujuan untuk mencari dan mengetahui karakteristik atau kondisi material serta kekurangan yang mungkin menyebabkan komponen mengalami kegagalan dan berbagai kegagalan yang tidak terlihat (Kumar and Mahto, 2013).

Akselerometer adalah sebuah sensor yang digunakan untuk mengukur getaran di atas permukaan tanah. dapat mengukur percepatan dinamis dan percepatan statis. Pengukuran dinamis adalah pengukuran percepatan pada objek bergerak, sedangkan pengukuran statis adalah pengukuran terhadap gravitasi 
bumi. Akselerometer juga dapat digunakan untuk mengukur getaran yang terjadi pada kendaraan, bangunan gedung bertingkat, dan mendeteksi getaran pada gempa bumi. Sensor akselerometer pada saat ini banyak digunakan dalam penelitian-penelitian ilmiah serta sebagai alat bantu dalam memantau aktivitas kegempaan (Bedon et al., 2018, Maizuar et al., 2020a).

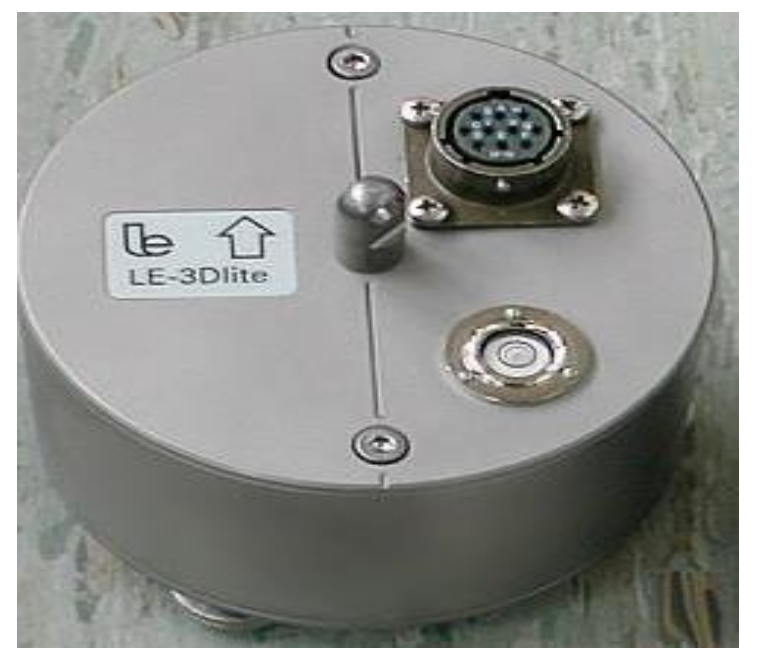

Gambar 1 Akselerometer sensor tiga sumbu (Z, NS dan EW)

Jumlah total jembatan di Indonesia diperkirakan 93.000 buah dan mayoritas jembatan sudah mempunyai umur rata-rata antara 25-50 tahun, sehingga kapasitas struktur jembatan mungkin telah mengalami penurunan (Imran et al., 2014). Salah satu penyebabnya adalah faktor usia jembatan yang sudah menua (ageing bridge), oleh karena itu, pemantauan perilaku struktur secara keseluruhan perlu dilakukan melalui pengukuran respon dinamik struktur (frekuensi alami dan lendutan).

Penelitian ini bertujuan untuk mengetahui perilaku dinamik jembatan melalui pengukuran respon dinamik struktur berupa frekuensi alami dan lendutan ketika dilalui beban lalu lintas dengan mengunakan sensor akselerometer. Hasil penelitian ini bisa dipakai untuk analisis lebih lanjut seperti untuk mendapatkan informasi tentang penilaian kondisi jembatan melalui perubahan frekuensi alamiahnya.

\section{Metode Penelitian}

Objek penelitian ini adalah Jembatan Alue Raya, Kecamatan Blang Mangat, Kota Lhokseumawe, Provinsi Aceh. Data struktur jembatan adalah sebagai berikut:

- Jenis konstruksi : : komposit

- Tipe jembatan : : kelas 1

- Panjang jembatan $\quad: 25,5 \mathrm{~m}$

- Lebar jembatan $\quad: 8,75 \mathrm{~m}$

- Jarak antar girder $\quad: 1,8 \mathrm{~m}$

- Lebar jalur lalu lintas $\quad: 7,25 \mathrm{~m}$

- Lebar trotoar : : 0,75 m 


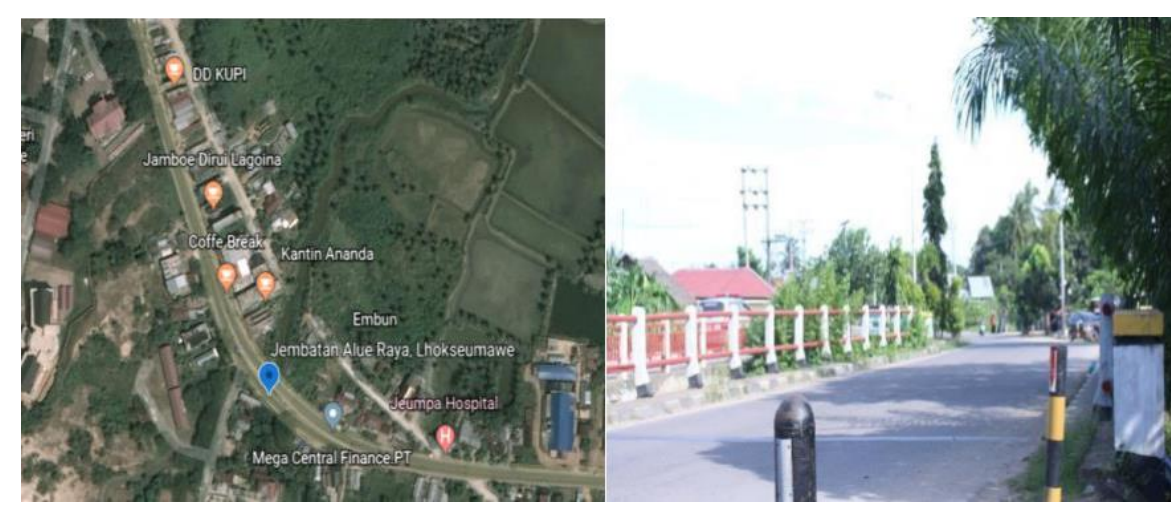

Gambar 2 Lokasi Penelitian

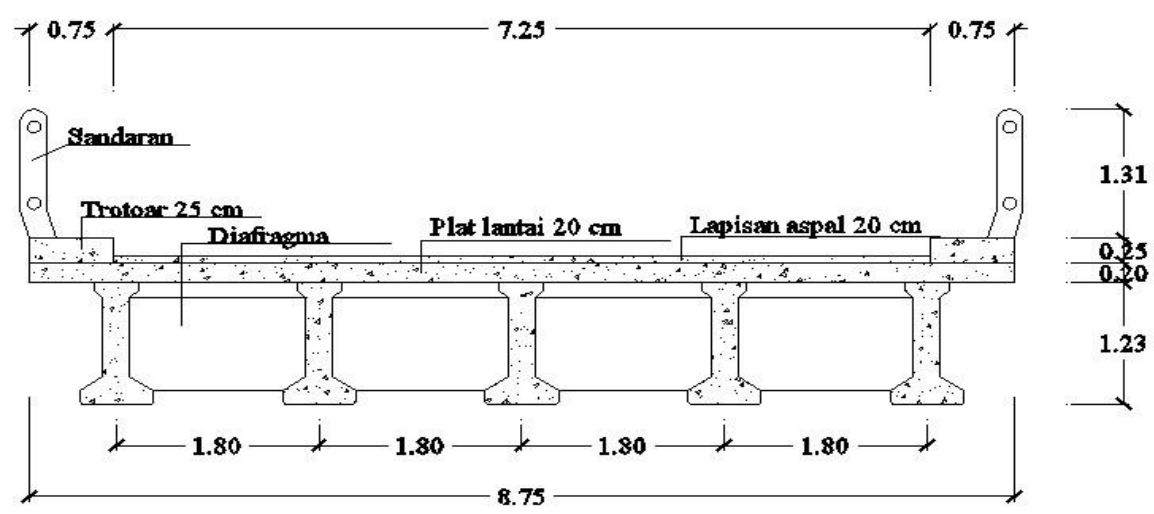

Gambar 3. Potongan melintang jembatan

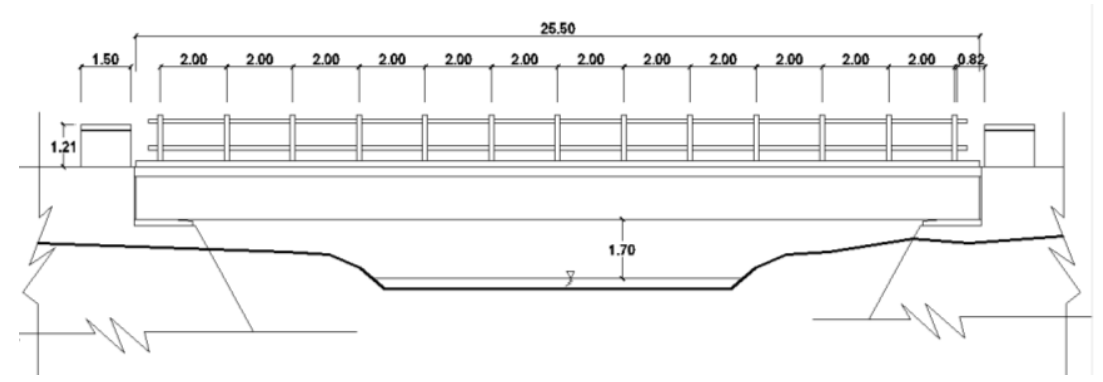

Gambar 4 Potongan memanjang jembatan

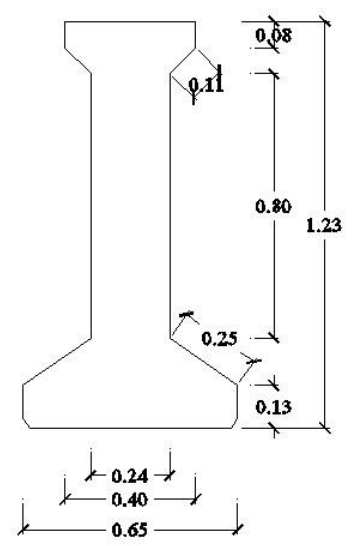

Gambar 5 Detail PCI Girder 


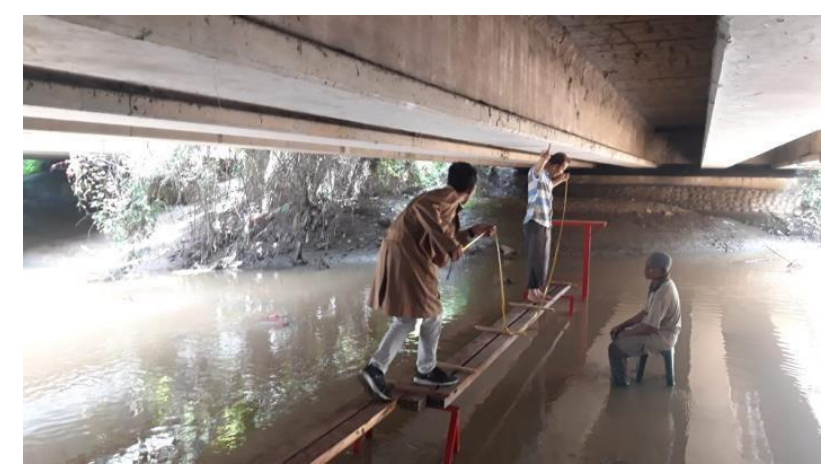

Gambar 6 Pemasangan sensor akselerometer pada girder jembatan

Langkah pertama yang dilakukan dalam penelitian ini adalah menentukan posisi perletakan sensor di tengah bentang girder. Kemudian menyiapkan alat-alat pendukung yang dibutuhkan seperti sumber daya yang berasal dari batere/ accu, menyiapkan dudukan/penyangga sensor dan memasang penyangga yang kaku pada girder untuk tempat perletakan sensor. Selanjutnya menyiapkan jembatan bantu memasang kabel penghubung antara sensor dengan digitizer dan memasukkan koordinat lokasi penelitian pada sensor. Kemudian antena GPS diletakkan pada area terbuka (terhindar dari pohon) dan melakukan set up waktu pada digitizer.

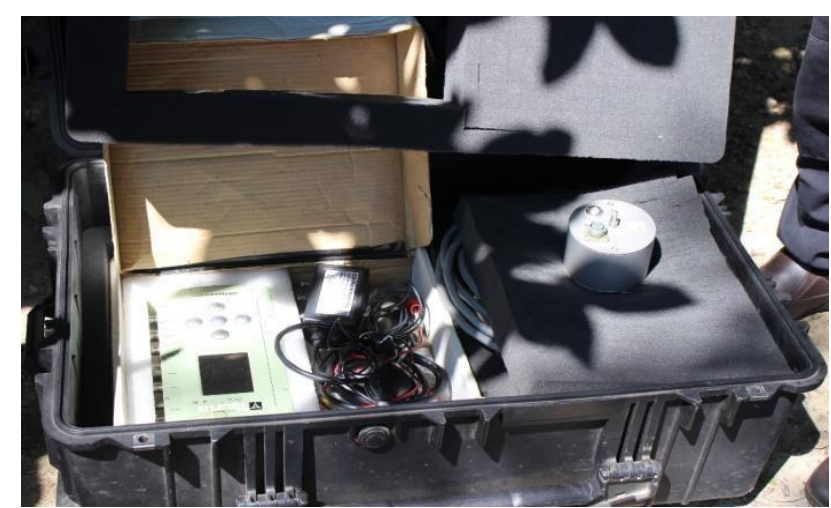

Gambar 7 Perangkat sensor akselerometer (sensor, digitizer, dan GPS)

Langkah berikutnya adalah melakukan uji pembebanan jembatan terhadap beban lalu lintas normal dan uji pembebanan dengan truk 28 ton selama 30 menit masing-masing sebanyak tiga kali percobaan.

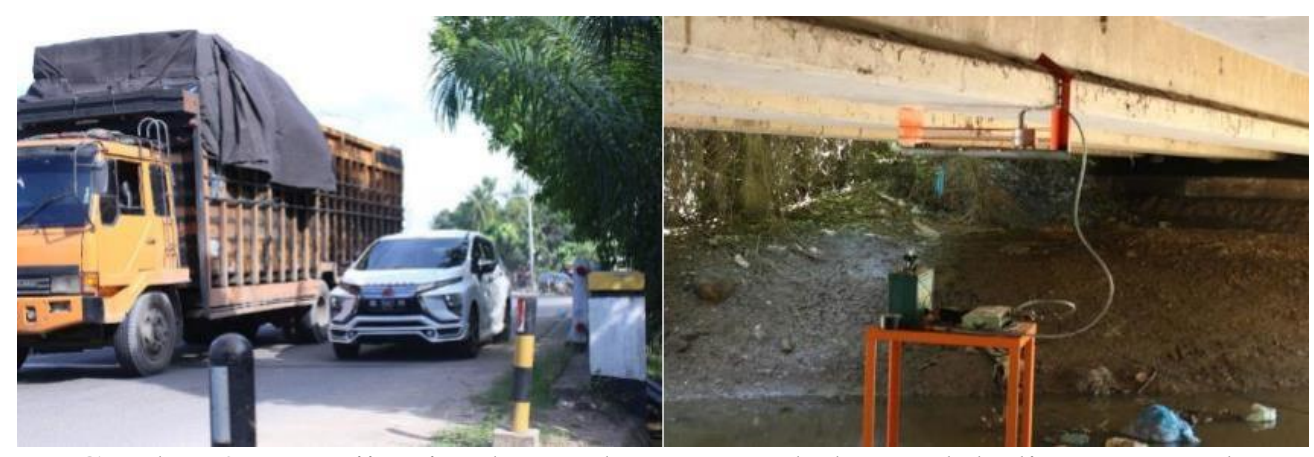

Gambar 8 Pengujian jembatan dengan pembebanan lalu lintas normal

Studi Eksperimen Perilaku Dinamik Jembatan Prestressed Concrete-I Girder Dengan Menggunakan Akselerometer - Said Jalalul Akbar, Maizuar, M. Fauzan, Burhanuddin 


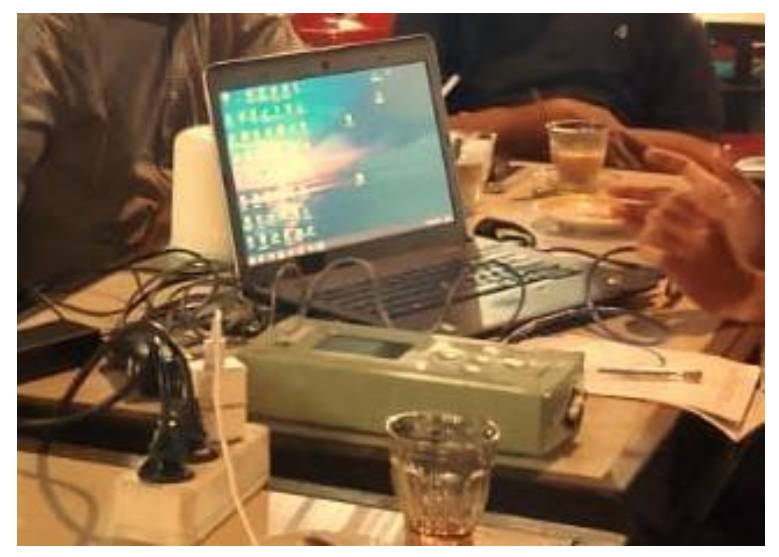

Gambar 9 Proses pemindahan data dari digitizer ke laptop

Untuk kepentingan analisis, data dipindahkan dari digitizer ke laptop, lalu data pengukuran dikonversi dari format data hexadecimal ke format SAF/Seed menggunakan software DATAPRO agar bisa diolah dan dianalisis dengan software Geopsy. Geopsy digunakan untuk mendapatkan frekuensi alami dari struktur. Selanjutnya data difilter, dan data tersebut disimpan. Untuk mendapatkan lendutan pada jembatan digunakan software DADiSP dengan metode integrasi yang sudah built-in pada software tersebut.

\section{Hasil dan Pembahasan}

Pada proses pengukuran vibrasi, sensor akan merekam data getaran yang dihasilkan dari aktivitas lalu lintas kendaraan yang selanjutnya akan dikirim ke digitizer. Data yang diterima oleh digitizer akan diproses pada komputer/laptop. Adapun GPS (Global Positioning System) berfungsi sebagai sistem penerima sinyal satelit yang memberikan informasi tentang koordinat sensor yang sedang dioperasikan. Selama sensor bekerja data-data yang dihasilkan selanjutnya dikirim secara kontinu ke digitizer dan disimpan dalam memory card yang terdapat pada digitizer tersebut. Pada pengujian ini, hasil yang diperoleh dari pengukuran perilaku dinamik dari jembatan berupa frekuensi alami, frekuensi dominan dan lendutan akibat dari beban lalu lintas normal serta lendutan maksimum akibat dari sebuah beban truk 28 ton.

Setelah melakukan pengukuran tiga kali percobaan, hasil pengujian dengan metode pengukuran berupa data signal gelombang dalam domain waktu kemudian dianalisis menggunakan software Geopsy dengan metode Horizontal to Vertical Spectral Ratio (HVSR) sehingga menghasilkan nilai (frekuensi alami). Selain untuk mengetahui frekuensi dari jembatan tersebut, hasil penngujian juga dapat memperoleh nilai lendutan maksimum yang terjadi pada jembatan dengan menggunakan bantuan software DADIsP, dimana data hasil pengujian tersebut diekspor terlebih dahulu dalam bentuk tipe data ASCII one column (no header) agar bisa terbaca pada software yang akan digunakan. DADiSP (Data Analysis and Display) adalah alat perangkat lunak grafis untuk menampilkan dan menganalisis data dari hampir semua sumber lingkungan komputasi numerik yang dikembangkan oleh DSP Development Corporation yang memungkinkan seseorang untuk menampilkan dan mengolah seri data, matriks dan gambar dengan antar muka yang mirip dengan spreadsheet. 
Pada Gambar 10 memperlihatkan hasil pengukuran frekuensi alami yang dihasilkan dari pengujian di lapangan yang diperoleh menggunakan software Geopsy dalam domain waktu. Sumbu $x$ memperlihatkan nilai frekuensi alami struktur jembatan sedangkan sumbu $y$ menunjukkan amplitude dari gelombang. Garis hitam tebal pada Gambar 10 menunjukkan nilai untuk frekuensi alami struktur $\left(\mathrm{f}_{0}=4,3256 \mathrm{~Hz}\right)$. Data yang dihasilkan dari perekaman akselerometer terdiri dari tiga sumbu yaitu sumbu vertikal (Z) serta dua sumbu di bawahnya horizontal yaitu Nort South (NS) dan Easting West (EW). Hasil pengukuran frekuensi alami sebanyak tiga percobaan untuk tiga sumbu diperlihatkan pada Tabel 1. Dalam analisis data, terlebih dahulu dilakukan filter terhadap data pengukuran vibrasi karena data yang dihasilkan sensor terdapat noise atau gangguan yang berasal dari aktivitas kendaraan maupun manusia. Dalam melakukan filtering data, di gunakan Band pass dengan rentang frekuensi dari $0,5 \mathrm{~Hz}$ hingga $10 \mathrm{~Hz}$. Adapun metode yang digunakan dalam melakukan filter data tersebut yaitu Butterworth filter dengan Butterworth filter order 1. Setelah melakukan filter tersebut perlunya dalam pemilihan window yang merupakan sinyal stasioner atau sinyal konstan. Hal ini dikarenakan sinyal tersebut tidak hanya bersumber dari aktivitas getaran pada girder tersebut tetapi juga disebabkan oleh adanya aktivitas yang bersumber dari getaran aktivitas manusia dan kendaraan.

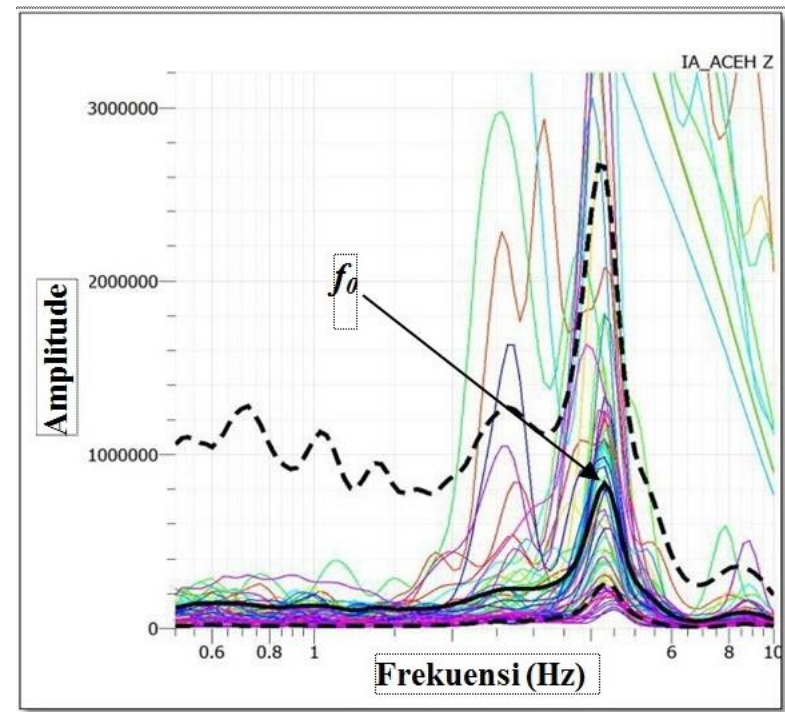

Gambar 10 Frekuensi alami jembatan pada pengujian 1 terhadap sumbu Z

Tabel 1. Hasil pengukuran frekuensi alami jembatan pada sumbu Z, NS dan EW

\begin{tabular}{|c|c|c|c|}
\hline Jenis Pengujian & Waktu & Sumbu & $\begin{array}{l}\text { Frekuensi } \\
\text { (HZ) }\end{array}$ \\
\hline \multirow{3}{*}{ Pengujian 1} & \multirow{3}{*}{$14.30-15.00 \mathrm{WIB}$} & $\mathrm{Z}$ & 4,3256 \\
\hline & & NS & 5,2180 \\
\hline & & EW & 5,2183 \\
\hline \multirow{3}{*}{ Pengujian 2} & \multirow{3}{*}{15.30 - $17.00 \mathrm{WIB}$} & $\mathrm{Z}$ & 4,3215 \\
\hline & & NS & 5,2603 \\
\hline & & EW & 5,1608 \\
\hline \multirow{3}{*}{ Pengujian 3} & \multirow{3}{*}{$17.30-18.00 \mathrm{WIB}$} & $\mathrm{Z}$ & 4,3355 \\
\hline & & NS & 5,2226 \\
\hline & & EW & 5,1426 \\
\hline
\end{tabular}

Studi Eksperimen Perilaku Dinamik Jembatan Prestressed Concrete-I Girder Dengan Menggunakan Akselerometer - Said Jalalul Akbar, Maizuar, M. Fauzan, Burhanuddin 
Setelah melakukan pemilihan window kemudian melakukan analisa spektrum H/V. Dalam melakukan proses windowing digunakan frekuensi filter band pass dari 0,5 sampai $10 \mathrm{~Hz}$, selanjutnya pada saat proses analisa dengan menggunakan analisa spectrum menggunakan parameter koreksi smoothing type Konno \& Ohmachi dengan smoothing constant sebesar 40 bandwith, selain itu menggunakan fungsi cosine taper sebesar 5\%. Setelah selesai melakukan setting terhadap parameter yang tersedia dalam software Geopsy dilanjutkan dengan analisa program dengan menjalankan perintah Start yang merupakan langkah terakhir dalam analisa data.

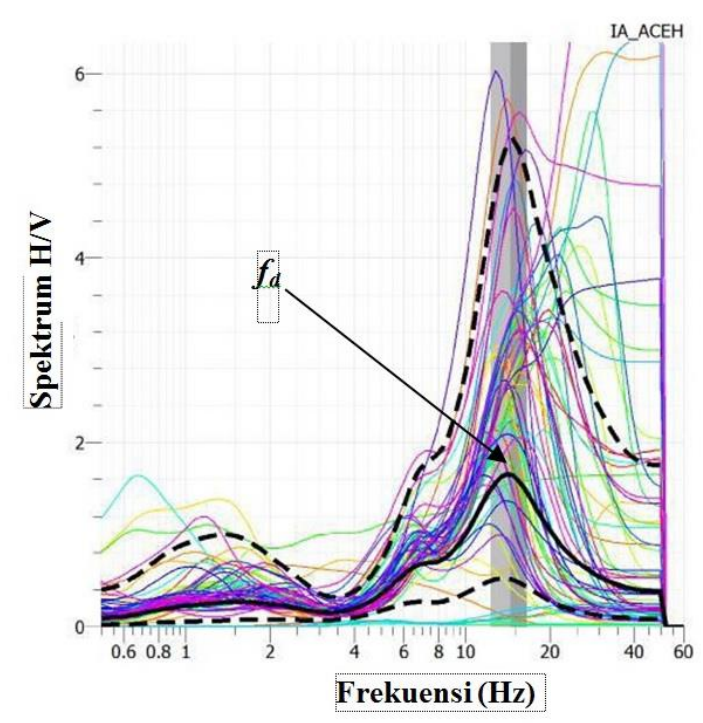

Gambar 11 Frekuensi dominan $f_{d}$ sebesar $14,7 \mathrm{~Hz}$ pada pengujian 1

Selain frekuensi alami, analisa spektrum H/V menghasilkan frekuensi dominan. Frekuensi dominan merupakan salah satu parameter yang penting dalam perencanaan struktur untuk menahan beban vibrasi akibat dari gempa bumi, angin, kendaraan maupun aktifitas manusia. Besaran frekuensi dominan $f_{d}$ yang terjadi pada sebuah struktur seperti jembatan tidak boleh sama dengan nilai frekuensi dominan akibat dari salah satu beban vibrasi karena akan mengakibatkan resonansi pada struktur jembatan. Frekuensi dominan $f_{d}$ sebesar $14,7 \mathrm{~Hz}$ pada pengujian 1 diperlihatkan pada Gambar 11.

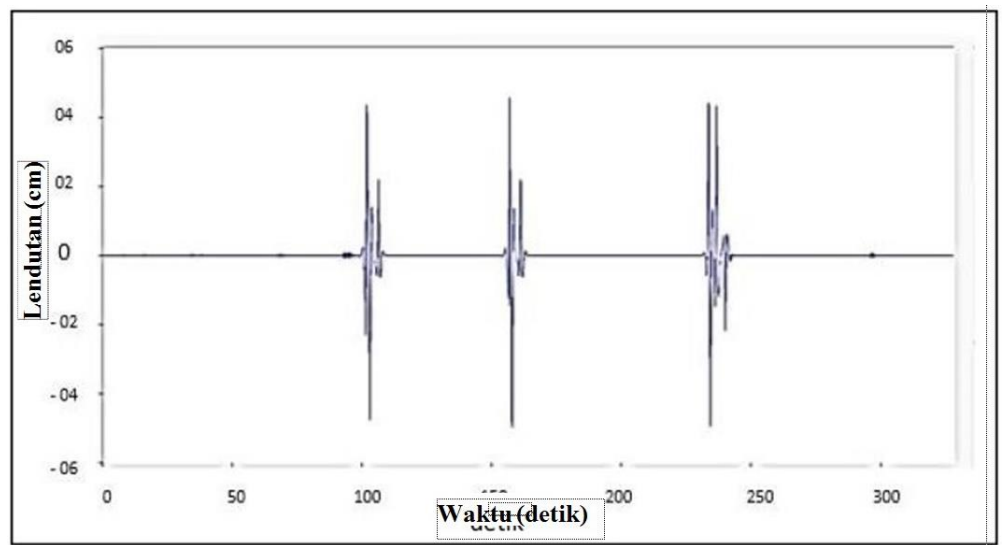

Gambar 12 Lendutan yang terjadi pada pengujian beban lalu lintas normal

Studi Eksperimen Perilaku Dinamik Jembatan Prestressed Concrete-I Girder Dengan Menggunakan Akselerometer - Said Jalalul Akbar, Maizuar, M. Fauzan, Burhanuddin 


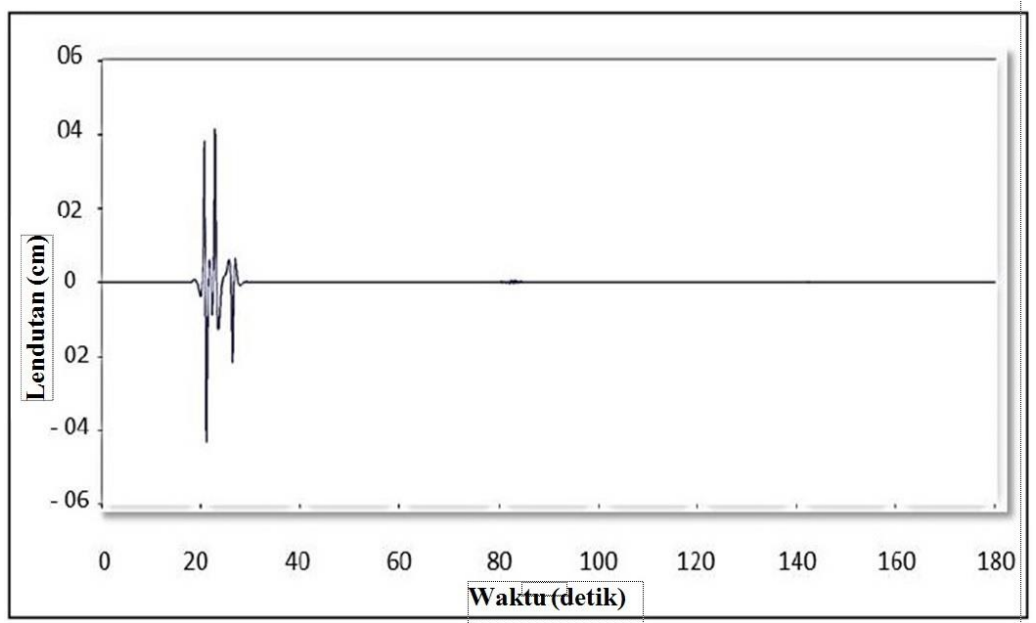

Gambar 13 Lendutan struktur jembatan pada pengujian dengan beban truk 28 ton

Lendutan yang terjadi pada struktur jembatan diperoleh dengan metode integral pada software DADiSP setelah data pengukuran vibrasi dikalikan dengan faktor koreksi lebih dahulu. Dari hasil analisis data menggunakan DADiSP, didapatkan hasil lendutan sebesar $0,5 \mathrm{~cm}$ akibat beban lalu lintas normal seperti diperlihatkan pada Gambar 12. Sedangkan lendutan struktur jembatan pada pengujian dengan beban truk 28 ton diperoleh sebesar $0,43 \mathrm{~cm}$ seperti diperlihatkan pada Gambar 13. Lendutan struktur jembatan yang diperoleh pada pengujian normal lebih besar dari pengujian beban truk 28 ton disebabkan oleh adanya beban truk dengan beban lebih dari 28 ton pada saat pengujian berlangsung.

\section{Kesimpulan dan Saran}

\subsection{Kesimpulan}

Jembatan yang sudah menua (ageing bridge) dan kenaikan beban lalu lintas akan mempengaruhi kapasitas struktur dan perilaku dinamik jembatan. Penelitian ini dilakukan untuk mengetahui perilaku dinamik jembatan melalui pengukuran respon dinamik struktur berupa frekuensi alami dan lendutan ketika dilalui beban lalu lintas dengan mengunakan sensor akselerometer. Hasil penelitian dari respon dinamik struktur diperoleh frekuensi alami sebesar 4,3256 Hz. Sedangkan lendutan diperoleh dengan menggunakan software DADiSP sebesar 0,43 cm pada pembebanan truk 28 ton dan lendutan sebesar $0,5 \mathrm{~cm}$ pada beban lalu lintas normal.

\subsection{Saran}

Pada penelitian selanjutnya, disarankan melakukan pemodelan jembatan dengan menggunakan metode numerik serta membandingkan dengan hasil yang diperoleh melalui eksperimen di lapangan.

\section{Ucapan Terima Kasih}

Penulis mengucapkan terima kasih kepada Hibah Penelitian Kemristek Dikti 2019 dan LPPM Universitas Malikussaleh yang telah membantu penelitian ini. 


\section{Daftar Kepustakaan}

Bedon, C., Bergamo, E., Izzi, M. \& Noè, S. 2018. Prototyping and validation of MEMS accelerometers for structural health monitoring - The case study of the Pietratagliata cable-stayed bridge. Journal of Sensor and Actuator Networks, 7, 30.

Chen, H.-P. 2018. Structural health monitoring of large civil engineering structures, John Wiley \& Sons.

Comisu, C.-C., Taranu, N., Boaca, G. \& Scutaru, M.-C. 2017. Structural health monitoring system of bridges. Procedia Engineering, 199, 2054-2059.

Imran, I., Hoedajanto, D. \& Zarkasi, I. 2014. Bridges in Indonesia: Present and future. International forum, JSCE century anniversary. Tokyo, Japan.

Kolakowski, P. 2007. Structural health monitoring-A review with the emphasis on low-frequency methods. Engineering Transactions, 55, 239-275.

Kumar, S. \& Mahto, D. 2013. Recent trends in industrial and other engineering applications of non destructive testing: A review. International Journal of Scientific \& Engineering Research, 4, 183-195.

Maizuar, Akbar, S. J. \& Salahuddin 2020a. Developing a low-cost vibration measurement system prototype for bridges using accelerometer sensors: A review. International Journal of Psychosocial Rehabilitation, 24, 12-19.

Maizuar, M., Akbar, S. J., Wesli, W. \& Burhanuddin 2019. Reliability-based approach for residual life prediction of bridges subjected to earthquake shocks degradation. Teras Jurnal-Jurnal Teknik Sipil, 9, 63-70.

Maizuar, M., Zhang, L., Miramini, S., Mendis, P. \& Duffield, C. 2020b. Structural health monitoring of bridges using advanced non-destructive testing technique. ACMSM25. Springer.

Zhang, L., Maizuar, M., Mendis, P., Duffield, C. \& Thompson, R. 2016. Monitor the dynamic behaviour of concrete bridges using non-contact sensors (IBISS). Applied Mechanics and Materials, 846, 225-230. 